Ks. Piotr SZCZUR*

\title{
FUNKCJA NAUCZYCIELSKA KOBIETY W MYŚLI JANA CHRYZOSTOMA
}

Ojcowie Kościoła i pisarze wczesnochrześcijańscy wielokrotnie wypowiadali się na temat funkcji, jakie kobiety - zwłaszcza chrześcijanki - powinny podejmować i pełnić w społecznościach, w których przyszło im żyć. Jednym z szeroko omawianych w starożytności problemów była kwestia prowadzenia przez kobiety nauczania. Zastanawiano się czy kobietom w ogóle można nauczać, a jeśli tak, to w jakich okolicznościach? W ten sposób usiłowano wskazać kobietom właściwą pozycję i miejsce w strukturach nauczania.

W wypowiedziach św. Pawła, które ze względu na swą wagę są podstawą dla nauczania Ojców Kościoła, wielokrotnie pojawiają się stwierdzenia, z których dość jasno wynika, że kobiety nie powinny zajmować się prowadzeniem nauczania. Dla przykładu warto przytoczyć najbardziej znaną wypowiedź, w której Apostoł Narodów wprost zabrania kobietom pouczania innych: „Kobieta niechaj się uczy w cichości z całym poddaniem się. Nauczać zaś kobiecie nie pozwalam ani też przewodzić nad mężem, lecz [chcę by] trwała w cichości" (1Tm 2, 11-12). Według wskazań Apostoła najlepiej by było, gdyby kobiety obecne na zgromadzeniach chrześcijan w ogóle się nie odzywały: „Kobiety mają na tych zgromadzeniach milczeć; nie dozwala się im bowiem mówić, lecz mają być poddane, jak to Prawo nakazuje. A jeśli pragną się czegoś nauczyć, niech zapytają w domu swoich mężów. Nie wypada bowiem kobiecie przemawiać na zgromadzeniu" (1Kor 14, 33-35). Nie dziwi więc fakt, że w wypowiedziach zdecydowanej większości pisarzy wczesnochrześcijańskich wskazania te znajdują swe odzwierciedlenie.

$\mathrm{W}$ niniejszym artykule postanowiono zbadać tę kwestię na podstawie wybranych wypowiedzi Jana Chryzostoma. W pierwszym punkcie prezentowanego opracowania zwrócimy uwagę na fakt iż w starożytności publiczne nauczanie i w ogóle przemawianie było manifestacją władzy i posiadanej pozycji społecznej. Następnie w dwóch kolejnych punktach przedstawimy wypowiedzi Chryzostoma na ten temat oparte na egzegezie tekstów biblijnych: drugiego rozdziału z Pierwszego Listu do Tymoteusza (punkt 2) i szesnastego

* Ks. dr hab. Piotr Szczur, prof. KUL - kierownik Katedry Historii Kościoła w Starożytności i Średniowieczu w Instytucie Historii Kościoła i Patrologii na Wydziale Teologii Katolickiego Uniwersytetu Lubelskiego Jana Pawła II; e-mail: p_szczur@kul.pl. 
rozdziału Listu do Rzymian (punkt 3). W końcowej partii artykułu przedstawimy podsumowanie i nasuwające się konkluzje.

\section{PRZEMAWIANIE PUBLICZNE JAKO PRZEJAW WŁADZY}

Ogólnie przyjmowane w starożytności normy społeczne podporządkowywały kobiety mężczyznom, dlatego posiadanie przez nie władzy nad mężczyznami było postrzegane jako sprzeczne $\mathrm{z}$ natura, przyzwoitością i zdrowym rozsądkiem ${ }^{1}$. Jednym zaś z przejawów władzy było publiczne przemawianie i nauczanie ${ }^{2}$. Mowy wygaszane publicznie były potężnym instrumentem władzy oraz podstawowym elementem manifestacji sprawowania urzędów świeckich i religijnych ${ }^{3}$. Isegoria (i $\left.\sigma \eta \gamma o p i \alpha^{4}\right)$ - prawo obywateli do publicznego zwracania się do rządowych instytucji polis, oraz parrezja $\left(\pi \alpha \rho \rho \eta \sigma^{\prime} \alpha^{5}\right)-$ prawo do swobodnej wypowiedzi w sprawach publicznych, dotyczyły jednak tylko mężczyzn ${ }^{6}$, a dokładniej - mężczyzn z elit politycznych ${ }^{7}$.

Niewiastom w zasadzie nie wolno było wypowiadać się publicznie ${ }^{8}$. Kobiety przedkładające swoje sprawy lub w jakikolwiek sposób wypowiadające się publicznie stanowią wyjątek i to często potępiany9. Rzymskie prawo zabraniało

${ }^{1}$ Por. np. Ocellus, De universi natura 49, ed. H. Thesleff, w: The Pythagorean Texts of the Hellenistic Period, Acta Academiae Aboensis, ser. A, Humaniora, Åbo 1965, 136, 22-24; Callicratidas, De domi felicitate 4, ed. H. Thesleff, w: The Pythagorean Texts of the Hellenistic Period, s. 106, 18-19.

${ }^{2}$ Por. Callicratidas, De domi felicitate 2, ed. Thesleff, s. 105, 14-17, gdzie autor thumaczy, że władza nauczyciela nad uczniem przynależy do funkcji nadzorowania i doglądania. Zob. D. Balch, Let Wives Be Submissive. The Domestic Code in I Peter, Society of Biblical Literature Monograph Series 26, Chico 1981, 26.

${ }^{3}$ Por. J.-P. Vernant, The Origins of Greek Thought, New York 1982, 49.

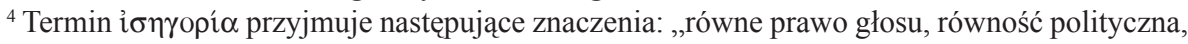

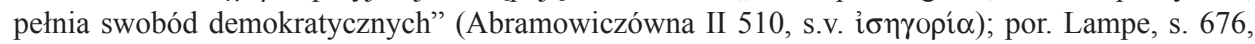

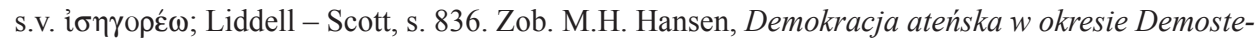
nesa: struktura, zasady i ideologia, thum. R. Kulesza, Warszawa 1999.

${ }^{5}$ Termin $\pi \alpha \rho \rho \eta \sigma i \alpha$ przyjmuje następujące znaczenia: „1. szczerość, otwartość, swoboda wypowiedzi, wolność słowa; 2. w ujemnym znacz. rozwiązłość języka, nieopanowanie w mowie; 3. swobo-

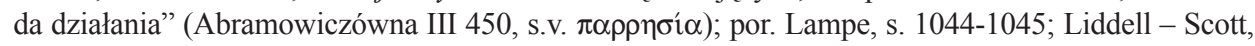
s. 1344. Zob. G. O'Collins - E.G. Farrugia, Leksykon pojęć teologicznych i kościelnych z indeksem angielsko-polskim, thum. J. Ożóg - B. Żak, Kraków 2002, 233; W. Zyzak, Parrezja, EK XIV 1374-1375.

${ }^{6}$ Por. L. McClure, Spoken Like a Woman: Speech and Gender in Athenian Drama, Pnnceton 1999, 9-15 i 19-22; H.M. Roisman, Women's Free Speech in Greek Tragedy, w: Free Speech in Classical Antiquity, ed. I. Sluiter - R.M. Rosen, Mnemosyne, Bibliotheca Classica Batava, Supplementum 254, Leiden - Boston 2004, 91-114, spec. 91.

${ }^{7}$ Por. Vernant, The Origins of Greek Thought, s. 61; K.U. Raaflaub, Aristocracy and Freedom of Speech in the Greco-Roman World, w: Free Speech in Classical Antiquity, s. 41-61, spec. 57.

${ }^{8}$ Por. McClure, Spoken Like a Woman: Speech and Gender in Athenian Drama, s. 37, gdzie autorka zauważa, że publiczne wypowiadanie się kobiet było postrzegane jako niebezpieczne właśnie z powodu powszechnego utożsamiania publicznego przemawiania z manifestacją władzy.

${ }^{9}$ Por. A.J. Marshall, Roman Ladies on Trial: The Case of Maesia of Sentinum, „Phoenix” 44 (1990) 46-59, spec. 56-58. 
kobietom dostępu do świeckich urzędów ${ }^{10}$ i pośrednio odmawiało prawa do publicznego wypowiadania się. Ogromna starożytna literatura etyczna pokazuje, że przyzwoita postawa kobiety zakłada jako regułę zachowanie milczenia w miejscach publicznych, a najlepiej również w okolicznościach prywatnych ${ }^{11}$.

Jak już wspomniano, nauczanie było powszechnie postrzegane jako wyraz władzy. Mężczyzna (mąż) był nieustannie definiowany jako nauczyciel kobiety, a w literaturze pojawiał się nawet topos, który potwierdzał tę władzę mężczyzny nad kobietą ${ }^{12}$. Kobieta - jak twierdzi Plutarch - powinna doceniać swojego męża jako instruktora, filozofa i nauczyciela w najbardziej wzniosłych i boskich kwestiach ${ }^{13}$. Nauczyciele-mężowie i uczniowie-żony znani są w różnych tradycjach filozoficznych ${ }^{14}$. Treści na ten temat można znaleźć nie tylko w tekstach greckich. Również rzymskie źródła potwierdzają rolę męża w intelektualnym nauczaniu żony, co ukazują np. listy Pliniusza ${ }^{15}$.

Nauczanie i rządzenie są wzajemnie powiązanymi kompetencjami mężczyzn. Neopitagorejczyk Kallikratidas mówi:

„[Mąż] powinien być dla swej żony nadzorca, panem i nauczycielem. Nadzorcą w zwracaniu bacznej uwagi na jej sprawy; panem w rządzeniu i sprawowaniu nad nią władzy; nauczycielem w nauczaniu jej rzeczy koniecznych, które powinna znać. Może to być szczególnie osiągnięte przez tego, który ożeni się z dziewicą. Dziewice takie są łatwo podatne na kształtowanie i potulne oraz szczególnie predysponowane do bycia pouczanymi oraz by lękać się i kochać swoich mężów"16.

${ }^{10}$ Por. J.E. Grubbs, Women and the Law in the Roman Empire: A Sourcebook on Marriage, Divorce and Widowhood, London - New York 2002, 74.

${ }^{11}$ Por. np. Plutarchus, Coniugalia praecepta 31-32. Zob. D. Budzanowska, ,, Coniugalia Praecepta” Plutarcha o życiu żon, VoxP 36 (2016) t. 65, 108: „Żona ma zatem mówić jedynie albo do męża, albo przez męża. Symbolem dobrej żony, domatorki zachowującej milczenie, jest według Plutarcha żółw (wykonany niegdyś przez Fidiasza dla Elejczyków)".

${ }^{12}$ Zwracano uwagę na obowiązki domowe żony, jej rolę macierzyńska, cnoty i zasady moralnofilozoficzne, które powinna posiadać, oraz wiedzę intelektualną (Plutarchus, Coniugalia praecepta 48).

${ }^{13}$ Por. Plutarchus, Coniugalia praecepta 48.

${ }^{14}$ Przykładami mogą być: Pitagoras i Teano; Krates z Teb i Hipparchia. Krates uczył Hipparchię podstaw filozofii i sposobu życia cyników. Na temat Hipparchii por. Diogenes Laertius, Vitae philosophorum VI 7, 96-98; J.M. Rist, Stoic Philosophy, Cambridge - London 1969, 61-62; R. Hawley, Practicing What You Preach. Plutarch's Sources and Treatment, w: Plutarch's Advice to the Bride and Groom, and A Consolation to His Wife, ed. S.B. Pomeroy, New York 1999, 116-127, spec. 124.

${ }^{15}$ Przykładowo Pliniusz Młodszy chwali swojego przyjaciela Saturninusa za doskonały styl listów jego żony. Podkreśla, że żona Saturninusa zawdzięcza tę umiejętność naukom, których udzielał jej mąż (Epistula 1, 16, 6). Odnotowuje także entuzjazm, z jakim Kalpurnia, jego żona, czyta jego pisma i uczy się ich na pamięć (Epistula 4, 19). Por. E.A. Hemelrijk, Matrona Docta. Educated Women in the Roman Elite from Cornelia to Julia Domna, London - New York 1999, 31-36; Ch. Kunst, Eheallianzen und Ehealltag in Rom, w: Frauenwelten in der Antike, Geschlechtsordnung und weibliche Lebenspraxis, hrsg. T. Späth - B. Wagner-Hasel, Stuttgart - Weinmar 2000, 32-52, spec. 40 i $46-47$.

${ }^{16}$ Callicratidas, De domi felicitate 4, ed. Thesleff, s. 107, 4-11, thum. własne. Por. K.S. Guthrie 
Inni pisarze antyczni wypowiadają się w podobnym duchu. Przykładowo Eliusz Arystydes twierdzi, że mężczyzna powinien uczyć swą żonę i rządzić nią tak, jak zwierzchnik rządzi poddanym; cechą męża powinno być mówienie, podczas gdy żona powinna charakteryzować się słuchaniem i milczeniem ${ }^{17}$. Kobieta nauczająca i pośrednio posiadająca władzę nad swoim mężem stanowi zaprzeczenie relacji pomiędzy naturalnym władcą i naturalnym poddanym, pomiędzy nauczycielem a osobą, która normalnie potrzebuje nauczania.

Według starożytnych konwencji kulturowych kobiety nie mogły wypowiadać się publicznie i sprawować władzy nad mężczyznami. To mężczyzna jest nauczycielem swej żony we wszystkich kwestiach. Kobiety nauczające mężczyzn wywracają tę naturalną relację. Nauczanie jest pewnego rodzaju urzędem i nie może być wykonywane przez kobiety, które - podobnie jak niewolnicy - nie moga posiadać władzy nauczyciela. Kobiety nie mają prawa nauczać mężczyzn, ponieważ są kobietami. Kwestia sprawowania władzy związana jest z niestosownością wystapień publicznych i toposem, według którego mężczyźni są naturalnymi nauczycielami kobiet.

\section{CHRYZOSTOMOWA EGZEGEZA 1TM 2, 11-15}

Cykl homilii na Pierwszy List do Tymoteusza najprawdopodobniej został wygłoszony w Antiochii ${ }^{18}$, gdy Jan był prezbiterem. Treść homilii 9., będącej przedmiotem naszego zainteresowania, koncentruje się na zakazie przemawiania w kościele i nauczania przez kobiety, oraz na wadze wychowania dzieci i edukacji ${ }^{19}$. Chryzostom mówi także o relacji pomiędzy płciami w kontekście analizy fragmentów Księgi Rodzaju opowiadających o stworzeniu człowieka i upadku prarodziców.

Nakaz zachowania przez kobiety milczenia w kościele (por. 1Tm 2, 11-12) Chryzostom wyjaśnia za pomocą innej wypowiedzi św. Pawła zaczerpniętej z 1Kor 14, 35: „Sromota bowiem jest niewiastom w kościele mówić”20. Po-

\footnotetext{
- D. Fideler, The Pythagorean Sourcebook and Library. An Anthology of Ancient Writings Which Relate to Pythagoras and Pythagorean Philosophy, Grand Rapids 1987, 236-237.

${ }^{17}$ Por. Aelius Aristides, Oratio 2, 128-130.

${ }^{18}$ Por. Quasten II 453; A. Cioffi, La preghiera nelle omelie di Giovanni Crisostomo sulla 1 Tm, w: Historiam Perscrutari. Miscellanea di studi offerti al. prof. Ottorino Pasquato, a cura di Mario Maritano, Bibioteca di Scienze Religiose 180, Roma 2002, 785; W. Mayer, The Homilies of St John Chrysostom: Provenance. Reshaping the Foundations, OCA 273, Rome 2005, 258. H. Savile jest zdania, że seria ta została wygłoszona w Konstantynopolu, natomiast L.S. Le Nain de Tillemont wskazuje na możliwość wygłoszenia jej w Konstantynopolu, por. tamże. Uczeni najczęściej wskazują, że homilie zostały wygłoszone w roku 394 lub 397, ewentualnie pomiędzy 394 a 397 rokiem, por. tamże, s. 268.

${ }^{19}$ Joannes Chrysostomus, In epistulam I ad Timotheum hom. 9 (CPG 4436), PG 62, 543-548, tłum. T. Sinko, w: Św. Jan Złotousty, Homilie na Listy Pasterskie św. Pawła i na List do Filemona (Tym. I, II. Tyt. Filem.), Kraków 1949, 95-101.

${ }^{20}$ Tamże 9, 1, PG 62, 543, thum. Sinko, s. 95.
} 


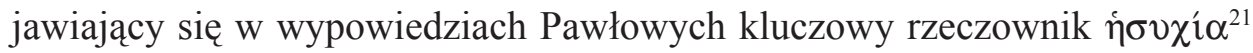
Chryzostom rozumie nie tylko jako cichą postawę (cichość) lecz przede wszystkim jako milczenie. Zachowanie milczenia w kościele ma wyrażać poddanie kobiety względem mężczyzny, ,tak bowiem przez milczenie okażą posłuszeń-

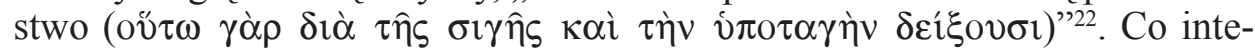
resujące, Chryzostom mówi najpierw o pogaduszkach kobiet w kościele, co zapewne było problemem w jego czasach:

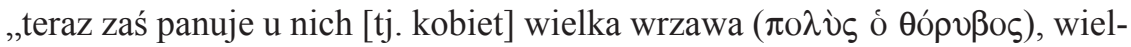

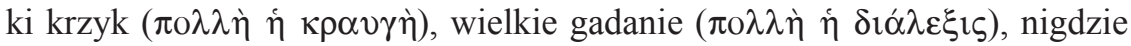
indziej nie tak wielkie, jak tu [tj. w kościele]. Można tu widzieć, że wszystkie mówią tyle, ile się nie słyszy ani na rynku, ani w łaźniach, jakby właśnie dlatego tu się zeszły, aby mieć swobodę: tak wszystkie spędzają czas na gadaniu o niepotrzebnych rzeczach ( $\tau \hat{\omega} v \dot{\alpha} v o v \eta \dot{\tau} \tau \omega){ }^{\prime \prime 23}$.

Rozmawiające w kościele kobiety powodują zgiełk i zamieszanie, co Chry-

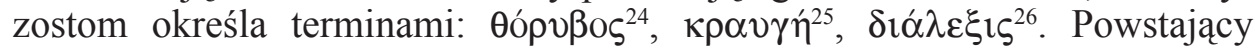
w ten sposób hałas jest większy od panującego na rynku lub w łaźni. Antiocheńczyk zwraca też uwagę na przedmiot rozmów prowadzonych przez kobiety. Podkreśla, że najczęściej mówią one rzeczach nieużytecznych ( $\tau \hat{\omega} v$ $\left.\dot{\alpha} v o v \eta \dot{\tau} \omega v^{27}\right)$. Jest to dla niego tym bardziej bulwersujące, gdyż - jak naucza - kobieta ,powinna milczeć, aby w kościele nie mówiła nie tylko o świeckich

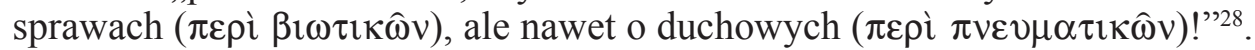
Pogaduszki, którym być może sprzyjało oddzielne umiejscowienie kobiet ${ }^{29}$,

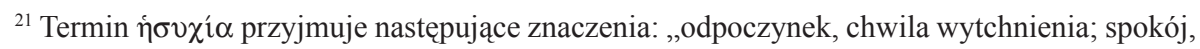
cisza; odpoczywać, być bezczynnym; żyć spokojnie, cieszyć się pokojem; nie reagować na coś;

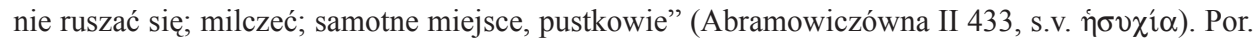
Lampe, s. 609-610; Liddell - Scott, s. 771.

${ }^{22}$ Joannes Chrysostomus, In epistulam I ad Timotheum hom. 9, 1, PG 62, 544, tłum. Sinko, s. 96.

${ }^{23}$ Tamże, PG 62, 543, tłum. Sinko, s. 95.

${ }^{24}$ Termin $\theta$ ópoßos przyjmuje następujące znaczenia: „1. hałas, wrzawa, krzyk; jako wyraz uznania lub niezadowolenia, oklaski; szemranie, pomruk; 3. zgiełk, zamieszanie; przerażenie" (Abramowiczówna II 468, s.v. Өópvßos); por. Liddell - Scott, s. 803-804.

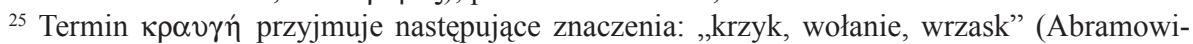

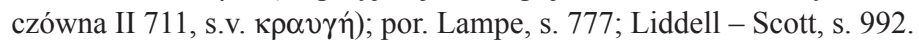

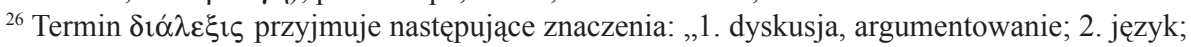

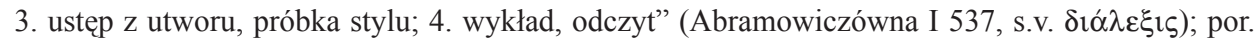
Lampe, s. 356; Liddell - Scott, s. 401.

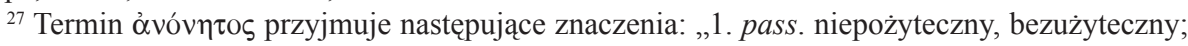

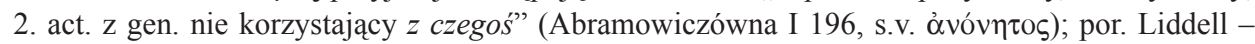
Scott, s. 147.

${ }^{28}$ Joannes Chrysostomus, In epistulam I ad Timotheum hom. 9, 1, PG 62, 543-544, thum. Sinko, s. 95.

${ }^{29}$ Por. tenże, In Matthaeum hom. 73, 3, PG 58, 677, tłum. J. Krystyniacki, w: Św. Jan Chryzostom, Homilie na Ewangelię wedlug św. Mateusza, oprac. A. Baron, t. 2, ŹMT 23, Kraków 2001, 366: „,nasi ojcowie uznali za rzecz konieczną przynajmniej deskami oddzielić was [tj. mężczyzn] od 
wydają się być bardziej namacalnym problemem w czasach Chryzostoma. Nawet, kiedy kaznodzieja nieco później przechodzi do nauczania prowadzonego przez kobiety, wydaje się bardziej koncentrować na rozmowach, podkreślając, iż Paweł chciał wyeliminować wszelkie okazje do tego, by kobiety mówiły w kościele. Podsumowując zaś - jak mu się wydawało - przesłanie wypowiedzi Pawłowych, wydał niezbyt pochlebną opinię o kobietach: „Rodzaj to

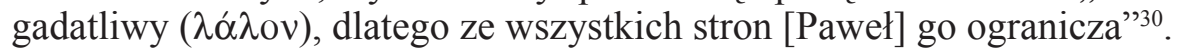

Złotousty kaznodzieja twierdzi, że jest kilka powodów zakazywania kobietom prowadzenia nauczania. Powołując się na wypowiedzi św. Pawła mówi, że pierwszym $\mathrm{z}$ nich jest pierwszeństwo i wyższość mężczyzny wynikające $\mathrm{z}$ aktu stworzenia:

„Rodzaj męski otrzymał większą cześć: pierwszy został stworzony (por. 1Tm 2,13). Gdzie indziej zaś [Paweł] pokazał większą cześć mówiąc: «albowiem nie jest stworzon mąż dla niewiasty, ale niewiasta dla męża» (1Kor 11, 9). Dlaczego więc to mówi? Bo chce, żeby mąż z rozmaitych względów miał pierwszeństwo" "31.

Nietrudno zauważyć, że Chryzostom wyprowadza swój argument z porządku stworzenia, który interpretuje przez pryzmat wypowiedzi Pawłowej z 1Kor 11, 9. Znamienne jest, że Antiocheńczyk kończy przytaczanie słów św. Pawła na wersecie 9. i pomija opisaną w wersach 11-12. wzajemność i współzależność mężczyzny i kobiety. Stąd też należy powiedzieć, że powyższe wyjaśnienie nie jest ani jednoznaczne, ani przekonujące.

Drugim powodem wprowadzenia zakazu nauczania przez kobietę jest jej rola, jaką odegrała w upadku człowieka.

„a po drugie z tego, co się stało (por. Rdz 3). Niewiasta pouczyła kiedyś męża, wszystko obaliła i uczyniła go winnym nieposłuszeństwa. Dlatego ją Bóg poddał pod władzę męża, bo źle użyła władzy ( $\propto \rho \chi \hat{n})$, a raczej równości

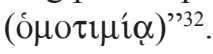

Złotousty kaznodzieja akcentuje, że u zarania dziejów kobieta wystapiła w roli nauczycielki mężczyzny. Jej nauczanie nie tylko doprowadziło do nieposłuszeństwa względem woli Boga, lecz także całą ludzkość przywiodło do ruiny. Ten pierwszy akt nauczania prowadzonego przez kobietę miał katastrofalne konsekwencje dla losu kolejnych pokoleń. Zatem to kobieta ponosi większą odpowiedzialność za upadek niż mężczyzna ${ }^{33}$.

nich [tj. kobiet]; lecz, jak słyszałem od starszych, dawniej nie było nawet takich przedziałów [...]. A za czasów apostolskich mężczyźni i kobiety byli razem". Zob. R.F. Taft, Women at Church in Byzantium, DOP 52 (1998) 27-87.

${ }^{30}$ Joannes Chrysostomus, In epistulam I ad Timotheum hom. 9, 1, PG 62, 544, thum. Sinko, s. 96.

${ }^{31}$ Tamże.

${ }^{32}$ Tamże.

${ }^{33}$ Por. tenże, De virginitate 46, 1-2, ed. H. Musurillo, SCh 125, Paris 1966, 258. Kobiety nieustannie prowadziły mężczyzn do upadku (tamże 46, 2, SCh 125, 258). Zob. C. Broc-Schmezer, Les 
Chryzostom naucza zatem, że mężczyzna - zgodnie z wolą Bożą ${ }^{34}$ - cieszy się wyższą godnością $\left(\tau \imath \mu \eta^{35}\right)$ nie tylko z powodu swego pierwszeństwa $\mathrm{w}$ akcie stworzenia, lecz także z powodu zaciagnięcia mniejszej winy za grzech pierwszych rodziców. Zatem poddanie kobiety mężczyźnie nie wynika jedynie z porządku stworzenia, lecz jest także konsekwencją upadku ${ }^{36}$. Bezpośrednio po akcie stworzenia kobieta cieszyła się taką samą ó $\mu$ o $\tau \mu$ í $\alpha^{37}$ (równą czcią/godnościa/, nie równością!) ${ }^{38}$, jednak grzech przemienił ją w poddanie - w stan porównywalny z niewolnictwem. Kobieta utraciła zatem swą

femmes de la Bible, reflets de l'évolution de Jean Chrysostome: A propos d'un passage du Traité sur la Virginité [XLVI, 2], w: Les Pères de l'Église et les femmes. Actes du Colloque de la Rochelle (6-7 sept. 2003), éd. P.G. Delage, Rochefort 2003, 150-168.

${ }^{34}$ Por. Joannes Chrysostomus, In Genesim ser. 2, 2, ed. L. Brottier, SCh 433, Paris 1998, 194, thum. S. Kaczmarek, ŹMT 45, Kraków 2008, 66: „Dlaczego zatem mężczyzna jest nazwany obrazem Boga, a niewiasta nie? Ponieważ nie mówi o obrazie wyrażonym przez formę, lecz o obrazie, który dotyczy władzy, jaką ma tylko mąż, a niewiasta jej nie posiada. On bowiem nikomu nie podlega; ona zaś stała się mu poddana, zgodnie ze słowami Boga: «Ku mężowi twemu twoje skierowanie, a on będzie nad tobą panował» (Rdz 3, 16). Dlatego mąż jest obrazem Boga, ponieważ nie ma nikogo nad sobą, tak jak nikt nie jest wyższy od Boga, ale panuje On nad wszystkimi, niewiasta jest natomiast chwałą męża, skoro jest mężowi podległa”. Chryzostom wyjaśnia, że to iż mężczyzna

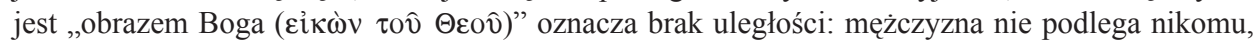
kobieta zaś jest podległa mężczyźnie. Zob. V. Karras, Male Domination of Woman in the Writings of Saint John Chrysostom, GOTR 36 (1991) 131-139, spec. 132-134; C.P. Schroeder, The Mystery of Love: Paradigms of Marital Authority and Submission in the Writings of St. John Chrysostom, VTQ 44 (2000) fasc. 2, 143-168, spec. 146; J. Dybała, Władza męża nad żona w nauczaniu Jana Chryzostoma, „Piotrkowskie Zeszyty Historyczne” 12 (2011) 4-17.

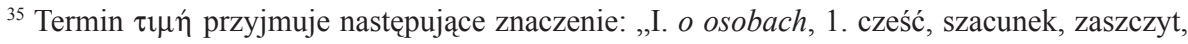
honor, wyróżnienie; 2. godność, dostojeństwo, majestat, przywilej, prerogatywa; 3. godność, urząd, stanowisko zaszczytne, 4 . honorowy dar, zaszczyt, nagroda; II. o rzeczach, 1. wartość, cena; 2. osza-

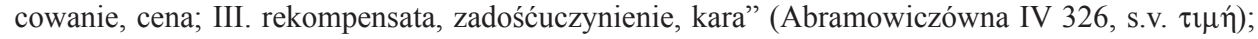
por. Liddell - Scott, s. 1793.

${ }^{36}$ Poddanie kobiety mężczyźnie jest także podyktowane względami praktycznymi w zarządzaniu gospodarstwem domowym, gdyż zapobiega nieporozumieniom i niezgodzie. Jan Chryzostom odrzuca „demokratyczne” idee w zarządzaniu gospodarstwem domowym, por. Joannes Chrysostomus, In epistulam ad Ephesios hom. 20, 4, PG 62, 141, tłum. M. Jurek, w: Św. Jan Chryzostom, O matzeństwie, wychowaniu dzieci i ascezie, BOK 19, Kraków 2002, 56-57: „Dlatego Bóg ją [tj. żonę] podporządkował, jego [tj. męża] zaś zobowiązał do troski, aby panował pokój. Gdzie bowiem małżonkowie mają takie same prawa, tam nie będzie pokoju. Nie jest dobrze, gdy w domu panuje demokracja i gdy wszyscy rządzą. Władza musi być jedna". Zob. E.A. Clark, The Virginal „Politeia” and Plat's „Republic”: John Chrysostom on Women and the Sexual Relation, w: taż, Jerome, Chrysostom and Friends. Essays and Translations, Studies in Women and Religion 1, New York - Toronto 1979, 1-34, spec. 1-2 i 22.

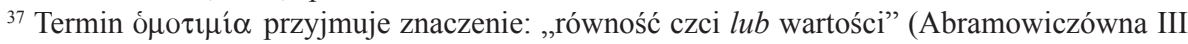
283, s.v. ó $\left.\mu \tau \tau \mu \mu^{\prime} \alpha\right)$; por. Lampe, s. 961; Liddell - Scott, s. 1228.

${ }^{38}$ Należy zauważyć, że greckie terminy ó ${ }$

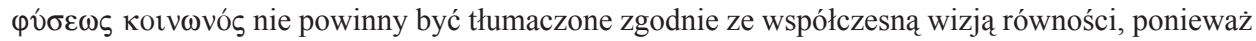
implikują wspólnotę natury ludzkiej i godności, a nie równość społeczną czy polityczną. 


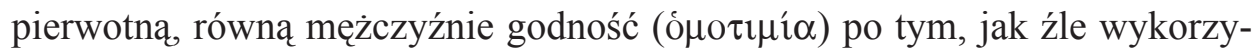

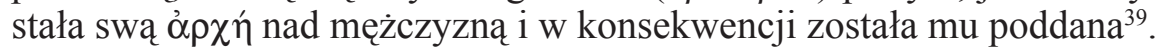

Wyjaśniając tę kwestię Chryzostom usprawiedliwia mężczyznę i pomniejsza jego udział w grzechu pierwszych rodziców. Opiera się przy tym na dosłownym odczytaniu słów Adama ( $\operatorname{Rdz} 3,12$ : „Niewiasta, którą postawiłeś przy mnie, dała mi owoc z tego drzewa i zjadłem") i na twierdzeniu, że jedynie kobieta uległa żądzy (Rdz 3, 6: „Wtedy niewiasta spostrzegła, że drzewo to ma owoce dobre do jedzenia"). Mężczyzna zgrzeszył tylko dlatego, że kobieta namówiła go do grzechu:

„Nie o Adamie powiedziano: «Ujrzał drzewo, że dobre było ku jedzeniu» (por. Rdz 3, 6), lecz że niewiasta ujrzała i jadła i dała także swojemu mężowi, tak, że ten nie żądzą ujęty dopuścił się przekroczenia, lecz po prostu słuchając niewiasty"40.

Przyznanie się Adama do tego, że „Niewiasta [...] dała mi owoc z tego drzewa i zjadłem" (Rdz 3, 12) jest wyraźnym potwierdzeniem, że mężczyzna nie został zwiedziony czy oszukany przez kobietę ${ }^{41}$, lecz tylko uległ jej namowom. Natomiast kobieta została zwiedziona i oszukana przez węża. Złotousty kaznodzieja twierdzi, że nawet gdyby Adam został zwiedziony przez Ewę, to i tak jego wina byłaby mniejsza niż jej, gdyż - jak argumentuje - nie jest

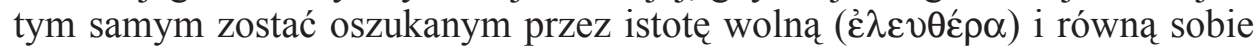

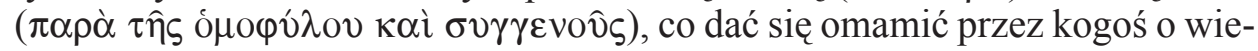

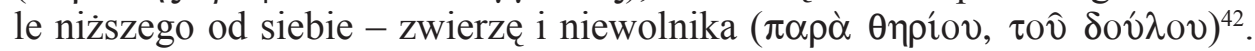
Dopuszczenie do sytuacji, w której istota niższa skutecznie oszukuje i zwodzi istotę wyższą jest prawdziwym zwiedzeniem i znakiem słabości ${ }^{43}$. Ewa oka-

${ }^{39}$ Por. Joannes Chrysostomus, In Genesim ser. 4, 1-2, SCh 433, 222-228, ŹMT 45, 74-76. Przyrodzona równa godność kobiety i mężczyzny została utracona, ponieważ niewiasta nie była w stanie zapanować nad grzesznymi popędami. Ponieważ nie doceniała wolności, została sprowadzona do poddaństwa. Zob. tenże, In Genesim hom. 17, 8, PG 53, 144-145; tenże, De virginitate 46, 1, SCh 125,256 , gdzie jest mowa o tym, że kobieta doprowadziła mężczyznę pod panowanie śmierci i dlatego straciła swój status duchowej towarzyszki.

${ }^{40}$ Por. tenże, In epistulam I ad Timotheum hom. 9, 1, PG 62, 545, thum. Sinko, s. 97.

${ }^{41}$ Por. tamże, tłum. Sinko, s. 96: „Adam zaś nie mówi: «Niewiasta mię zwiodła», lecz «Ona mi dała i jadłem» (Rdz 3, 16)".

${ }^{42}$ Warto zauważyć, że Chryzostom nie utożsamia węża z szatanem ( $\delta$ ióßoגos), jak na ogół ma to miejsce w tradycji patrystycznej.

${ }^{43}$ Por. Joannes Chrysostomus, In epistulam ad Romanos hom. 31, 4, PG 60, 673, thum. W. Sinko: Św. Jan Chryzostom, Homilie na list św. Pawła do Rzymian, oprac. A. Baron, t. 2, Kraków 1998, 458: „Zgrzeszył Adam i zgrzeszyła Ewa, oboje przekroczyli zakaz, lecz nie jednakowo zgrzeszyli, a więc nie jednakowo zostali ukarani (por. Rdz 3, 1-19). Taka była między nimi różnica, że Paweł powiedział: «Adam nie został zwiedziony, a żona jego zwiedziona dopuściła się przekroczenia» (1Tm 2, 14). Jakkolwiek zwiedzenie było jedno, mimo to dokładne rozważenie sprawy przez Boga wykazało różnicę, która skłoniła Pawła do wypowiedzenia przytoczonych słów"; tenże, Epistula 10 (3) [Do Olimpias], 3a, ed. A.-M. Malingrey, SCh 13bis, Paris 1968, 248, gdzie twierdzi, że wina kobiety jest o wiele poważniejsza niż wina mężczyzny, gdyż w porównaniu z tym, co zrobiła kobieta 
zała się zatem istotą słabą: poddała się swym żądzom i nie oparła się pokusie marnego stworzenia. Antiocheńczyk zauważa, że chociaż upadek dotyczył Ewy, to jednak jej słabość przeszła na wszystkie niewiasty, „rodzaj to bowiem

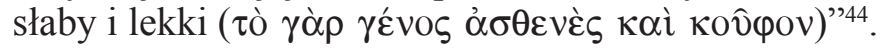

Kobieta z 1Tm 2, 14 stanowi zarówno typ jak i zbiorową osobę, podobnie jak Adam z Rz 5, 1445. Jednak w Liście do Rzymian autor kładzie nacisk na Adama jako typ Chrystusa (nie upadłej ludzkości), natomiast w Pierwszym Liście do Tymoteusza Ewa reprezentuje upadłą płeć żeńską. Z powodu wrodzonej kobiecej naiwności, zakaz nauczania dotyczy wszystkich kobiet. Jan Chryzostom dochodzi da takiego samego wniosku w jednej z homilii na Księgę Rodzaju:

„Posłuchaj, co o tym poddaństwie mówi św. Paweł [...]: «Niewiasta - rzecze - niech się uczy w cichości, w pełnym poddaniu się» (1Tm 2, 11). Czy widzisz, że i on poddał niewiastę mężowi? Ale poczekaj, by usłyszeć powód znowu ten sam. Dlaczego: «W całym poddaniu się» $(1 \mathrm{Tm} 2,11)$ ? «Niewieście natomiast - rzecze - nie pozwalam nauczać» $(1 \mathrm{Tm} 2,12)$, bo raz źle pouczyła Adama. «Ani żeby miała władzę nad mężem» $(1 \mathrm{Tm} 2,12)$, bo raz źle użyła władzy. «Adam bowiem - rzecze - nie został zwiedziony, niewiasta natomiast po zwiedzeniu dopuściła się przestępstwa» $(1 \mathrm{Tm} 2,14)$. Dlatego usunął ją z nauczycielskiego tronu ( $\delta ı \delta \sigma \sigma \alpha \lambda \lambda_{i} \alpha \varsigma$ $\theta$ óvov). Ten zatem, kto nie umie pouczać, niech się uczy. Gdyby nie chciał się uczyć, lecz pragnąłby pouczać, i siebie samego zgubi, i w dodatku uczniów; do tego właśnie doszło wówczas w przypadku niewiasty" ${ }^{\prime 4}$.

Pomimo to, w innym miejscu Chryzostom twierdzi, że w pewnych okolicznościach kobiety mogą nauczać.

\section{CHRYZOSTOMOWA EGZEGEZA RZ 16, 3-16}

Chryzostomowy komentarz do tekstu Rz 16, 3-16, w którym poruszany jest temat nauczających kobiet, znajduje się w dwóch homiliach. Pierwsza z nich, to stanowiący oddzielną całość panegiryk na cześć Pryscylli i Akwili:

wina mężczyzny tak naprawdę nie jest grzechem. Jednak Jan Chryzostom nie jest konsekwentny w wyrażaniu tego przekonania. Przykładowo, w jednej z homilii na Księgę Rodzaju Antiocheńczyk wyraźnie mówi o grzechu Adama i przekroczeniu przez niego prawa. Zob. tenże, In Genesim ser. 3, 2, SCh 433, 214, ŹMT 45, 72: „Adam odrzucił całe polecenie i przekroczył prawo”.

${ }^{44}$ Tenże, In epistulam I ad Timotheum hom. 9, 1, PG 62, 545, thum. Sinko, s. 97. Por. Broc-Schmezer, Les femmes de la Bible, reflets de l'évolution de Jean Chrysostome, s. 159-160, gdzie autorka analizuje fragment 29. homilii na List do Hebrajczyków, w którym jest mowa, iż kobiety są słabe nie tylko z natury, lecz także z powodu trybu życia i otrzymywanej edukacji zachęcających je do delikatności i bezczynności.

${ }^{45} \mathrm{Na}$ temat grzech Adama w interpretacji Chryzostoma zob. E. Pagels, The Politics of Paradise: Augustine's Exegesis of Genesis 1-3 versus that of John Chrysostom, HTR 78 (1985) 67-99; P. Papageorgiou, Chrysostom and Augustine on the Sin of Adam and Its Consequences, VTQ 39 (1995) 361-378.

${ }^{46}$ Joannes Chrysostomus, In Genesim ser. 4, 1, SCh 433, 226, ŹMT 45, 75. 
Salutate Priscillam et Aquilam ${ }^{47}$, wygłoszony prawdopodobnie w Antiochiii ${ }^{48}$ $\mathrm{w}$ roku $388^{49}$. Druga natomiast jest jedną z homilii na List do Rzymian (hom. $31)^{50}$. Uczeni prawie jednoznacznie wskazują, że ten cykl homilii również został wygłoszony w Antiochii ${ }^{51}$. W homiliach tych złotousty kaznodzieja analizuje rolę Pryscylli i innych wczesnochrześcijańskich kobiet w upowszechnianiu ewangelii i wspieraniu Kościoła. Egzegeza tych tekstów Pawłowych prowadzi Chryzostoma do wniosku, że zakaz nauczania zawiera pewne wyjątki.

Powracającym motywem jest wspominanie Pryscylli pouczającej Apollosa (por. Dz 18, 26). Paweł wspomina też Pryscyllę jako pierwszą z powodu jej

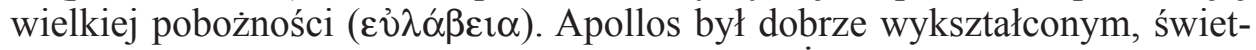
nie znającym Pismo i elokwentnym wierzącym Żydem, ale posiadał wiedzę jedynie o chrzcie Jana (por. Dz 18, 24-25). Pryscylla zatem ,przyjęła Apollosa

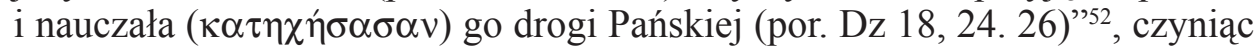
$\mathrm{z}$ niego doskonałego nauczyciela ${ }^{53}$. Interesujące jest, że Chryzostom koncentruje się na dokonaniach Pryscylli całkowicie przemilczając rolę Akwili. Warto też podkreślić, iż mówiąc o roli nauczycielskiej Pryscylii Antiocheńczyk

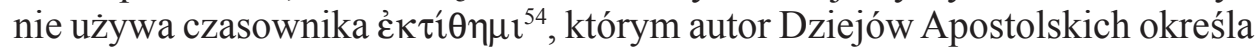
nauczanie Apollosa przez Pryscyllę (por. Dz 18, 26), lecz posługuje się czasow-

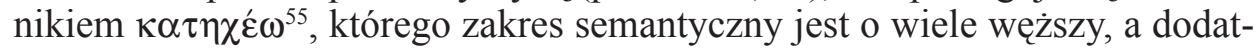
kowo wskazuje na treść nauczania. Ponadto złotousty kaznodzieja stwierdza, że Pryscylla sprawiła, iż Apollos stał się ,pełnym nauczycielem ( $\delta$ i $\delta \alpha \sigma \kappa \alpha \lambda$ ov $\left.\dot{\alpha} \pi \eta \rho \tau \iota \sigma \mu \varepsilon^{\prime} v o v\right) " 56$. Pryscylla nie jest przykładem odosobnionym:

„[Pryscylla] nie była jedyna, która postępowała w ten sposób. Wszystkie inne robiły to samo. Albowiem Persydę, o której [Paweł] powiedział: «Która wiele

${ }^{47}$ Tenże, In illud: Salutate Priscillam et Aquilam (Rz 16, 3) ser. 1, PG 51, 187-196.

${ }^{48}$ Por. Mayer, The Homilies of St John Chrysostom, s. 256.

${ }^{49}$ Por. tamże, s. 264.

${ }^{50}$ Joannes Chrysostomus, In epistulam ad Romanos hom. 31, PG 60, 667-676, tłum. Sinko, t. 2, s. $448-461$.

${ }^{51}$ Por. Quasten II 445; Mayer, The Homilies of St John Chrysostom, s. 258. Jednak G. Rauschen jest zdania, że prawdopodobnie homilie te zostały wygłoszone w Konstantynopolu, por. tamże, s. 267.

${ }^{52}$ Joannes Chrysostomus, In epistulam ad Romanos hom. 30, 2, PG 60, 664, thum. Sinko, t. 2 , s. 441. Por. tamże 31, 1, PG 60, 669.

${ }^{53}$ Por. tenże, In illud: Salutate Priscillam et Aquilam ser. 1, 3, PG 51, 191-192.

${ }^{54}$ Termin $\dot{\varepsilon} \kappa \tau i \theta \eta \mu \imath$ przyjmuje następujące znaczenia: „I. act. 1. wystawiać, umieszczać na zewnątrz; wysadzać na bezludnej wyspie; porzucać, o noworodku; wyrzucać kogoś skadś; 2. wyznaczać jako nagrodę; 3. wystawiać na widok publiczny; 4. wystawiać na sprzedaż; 5. wykładać, wyjaśniać; 6. wyrozumować; II. med. 1. wywozić; 2. wyodrębniać; 3. ustalać terminy w trybie sylogistycznym; 4. wybierać, wyłączać celem odrębnego traktowania; 5. wykładać, wyjaśniać" (Abra-

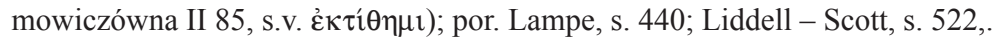

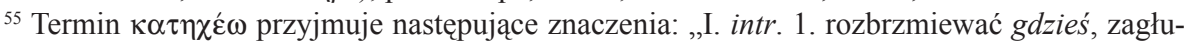
szać, o miejscu majacym zła akustykę; II. trans. 1. uczyć ustnie, pouczać; pass. być informowanym;

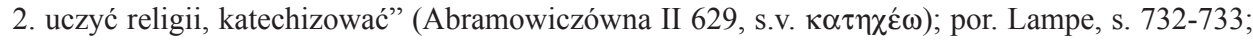
Liddell - Scott, s. 927.

${ }^{56}$ Joannes Chrysostomus, In illud: Salutate Priscillam et Aquilam ser. 1, 3, PG 51, 192. 
trudu poniosła dla nas» $(\mathrm{Rz} 16,12)$ i Marię, i Tryfenę wychwala z powodu takich samych czynów, iż pracowały razem z apostołami i były przygotowane na takie same zmagania $(\dot{\alpha} \gamma \hat{\omega} v \alpha \varsigma) "{ }^{\prime 57}$.

Omawiaja postawę Pryscylli i innych kobiet wspomnianych w Rz 16, a zaangażowanych w misję Pawła, Chryzostom przywołuje 1Tm 2, 12, aby wyjaśnić pewnego rodzaju sprzeczność istniejąca pomiędzy przykładami wspomnianych kobiet, a zakazem nauczania:

„Cóż zatem znaczą słowa Pawła: «Niewieście nauczać nie pozwalam» (1Tm 2, 12). Zakazuje jej przewodniczyć wśród zgromadzenia (por. 1Kor 14, 35), usuwając ją z katedry i podwyższenia, a nie od nauczania słowem. Gdyby bowiem tak było, jak mógłby przemówić do niewiasty, mającej męża niewierzącego: «Skądże możesz wiedzieć, niewiasto, że zbawisz męża?» (1Kor $7,16)$. Jakżeby pozwolił upominać synów, mówiąc: «Zbawiona zaś zostanie [niewiasta] przez rodzenie dzieci, jeżeli pozostaną w wierze, miłości i świątobliwości - ze skromnością» (1Tm 2, 15)? W jaki sposób Pryska nauczyła wiary Apolla (por. Dz 18, 24-26)? Nie wyraził się w ten sposób, aby przeszkodzić osobistej i pożytecznej perswazji, lecz aby [wskazać], że przemawianie podczas zgromadzenia jest zadaniem nauczyciela" ${ }^{58}$.

Z przytoczonego tekstu jasno wynika, że zakaz nauczania przez kobiety nie jest bezwzględny. Jan Chryzostom ogranicza jego zakres i wskazuje na trzy wyjątki. Kobiecie wolno nauczać kiedy czyni to we własnej rodzinie (wierząca, pobożna i mądra kobieta może nauczać niewierzącego męża i dzieci), kiedy naucza prywatnie, kiedy prowadzone przez nią nauczanie nie wchodzi w zakres władzy przynależnej urzędowi kościelnemu i nie łączy się z nim.

1. Nauczanie w domu. Kobieta nie może nauczać mężczyzny, gdy on sam wyznaje tę samą wiarę, jest pobożny i prawy oraz jest w stanie nauczać swoją żonę ${ }^{59}$. Jeśli zaś mężczyzna jest niewierzący i nieroztropny, a jego żona jest mądrzejsza, apostoł nie pozbawia jej władzy do nauczania ${ }^{60}$, nie powstrzymuje

${ }^{57}$ Tamże, tłum. własne. Por. tenże, In Matthaeum hom. 73, 3-4, PG 58, 677, ŹMT 23, 366-367: „Posłuchajcie więc, co mówi kobieta, która sprzedawała purpurę (por. Dz 16, 14): «Jeżeli uważacie mnie za wierną Panu, to przyjdźcie do mego domu i zamieszkajcie w nim» (Dz 16, 15). Posłuchajcie kobiet, które nabrawszy ducha męskiego, towarzyszyły apostołom: Pryscylli (por. Dz 18, 2. 18. 26), Persidy (por. Rz 16,12) i innych; dzisiejsze kobiety tak się od nich różnią, jak mężczyźni od prawdziwych mężczyzn. [...] Wówczas tamte kobiety starały się rozgłaszać Ewangelię, a teraz starają się o to, by uchodzić za urodziwe, ładne i dobrze wyglądające. To jest ich sława, ich zbawienie; a o wielkich i wzniosłych czynach nawet się im nie śni”.

${ }^{58}$ Tenże, In epistulam ad Romanos hom. 31, 1, PG 60, 669, thum. Sinko, t. 2, s. 450-451.

${ }^{59}$ Por. tamże, tłum. Sinko, t. 2, s. 451: „A jeśli znowu mąż jest wierzący i pełen prawości, ma prawo uczyć żonę".

${ }^{60}$ Por. tenże, In illud: Salutate Priscillam et Aquilam ser. 1, 3, PG 51, 192. 
jej przed uczeniem i prowadzeniem go ku poprawie ${ }^{61}$. To dopuszczenie kobiety do nauczania męża oparte jest na wypowiedziach św. Pawła z 1Kor 7, 13 i 16, które sugerują, że mądra kobieta-chrześcijanka może zbawić swego męża ${ }^{62}$ po-

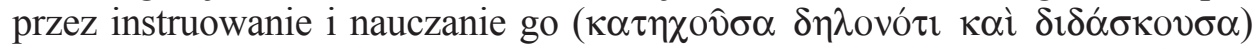
oraz prowadzenie go do wiary, tak jak uczyniła to Pryscylla z Apollosem ${ }^{63}$. Ten sam argument można znaleźć w 5. homilii (z serii pierwszej) Jana Chryzostoma na Księgę Rodzaju. Odnosząc się do 1Kor 7, 13, kaznodzieja uznaje, że kobieta-chrześcijanka może nauczać swego niewierzącego męża. Jako wierząca nie błądzi, podczas gdy niewierzący mąż został zwiedziony i błądzi. W konsekwencji, kobieta zostaje ponownie wyniesiona na tron nauczania:

„Kiedy mężczyzna jest niewierzący a niewiasta wierząca, niech poucza niewiasta. Dlaczego? Gdyż nie ulega zwiedzeniu, bo jest wierząca. Pouczany niech będzie mąż, gdyż został zwiedziony i jest niewierzący. Zostało odwrócone to, co się tyczy nauczania, niech więc będzie odwrócone także to, co się tyczy panowania [...]. Na początku udziałem niewiasty stało się zwiedzenie, a do zwiedzenia przyłączyło się bycie poddaną. Kiedy zaś zwiedzenie przeniosło się później na męża, przeniosło się i bycie poddanym. I jak na początku mężczyźnie, który nie uległ zwiedzeniu, powierzył zbawienie niewiasty [...], tak tutaj, w przypadku wierzącej, która ma niewierzącego męża, zbawienie mężczyzny powierzył niewieście" ${ }^{\circ 4}$.

W tym kontekście wychwalanie Pryscylli przez Chryzostoma za nauczanie Apollosa jest niezwykłe, ponieważ był on przecież człowiekiem wierzącym, doskonale wykształconym i bardzo dobrze znającym Pismo. Co więcej - sam był dla innych nauczycielem wiary, a nie niewierzącym, jak mężczyzna, o którym jest mowa w 1 Kor 7, 13 i 16. Wprawdzie wiara Apollosa była niepełna i posiadała pewne braki (wiara w chrzest Janowy), ale z pewnością istniała.

Rola kobiety jako nauczycielki realizowana jest również wobec jej dzieci. Interesujące jest, że Chryzostom jako argument przemawiający za władzą nauczycielską kobiety rozciaggającą się na dzieci przywołuje wypowiedź św. Pawła z Pierwszego Listu do Tymoteusza $(2,15)^{65}$, z której trudno jest wyciagnąć taki wniosek, gdyż tekst ten podkreśla, a w zasadzie ogranicza, rolę kobiety do macierzyństwa. Jednak Chryzostom przywołując tę wypowiedź Pawłową koncentruje się na roli matki w przekazywaniu dzieciom wiedzy religijnej i prowadzeniu edukacji moralnej. Czyni tak, aby wykazać, że zakaz nauczania przez kobiety nie może być generalizowany i bezwzględnie stosowany.

${ }^{61}$ Por. tenże, In epistulam ad Romanos hom. 31, 1, PG 60, 669, thum. Sinko, t. 2, s. 451: „Gdy zaś ona jest mądrzejsza, [Paweł] nie przeszkadza jej uczyć i poprawiać męża”.

${ }^{62}$ Por. tenże, In illud: Salutate Priscillam et Aquilam ser. 1, 3, PG 51, 192; tenże, In epistulam ad Romanos hom. 31, 1, PG 60, 669.

${ }^{63}$ Por. tenże, In illud: Salutate Priscillam et Aquilam ser. 1, 3, PG 51, 192.

${ }^{64}$ Tenże, In Genesim ser. 5, 1, SCh 433, 256-258, ŹMT 45, 84.

${ }^{65}$ Por. tenże, In epistulam ad Romanos hom. 31, 1, PG 60, 669. 
Największym sukcesem rodziców w wychowaniu dzieci jest uczynienie ich ludźmi cnotliwymi ${ }^{66}$. W dłuższym passusie 9. homilii na Pierwszy List do Tymoteusza, skierowanym zwłaszcza do chrześcijańskich rodziców ${ }^{67}$, Chryzostom opisuje wychowywanie dzieci jako „dobry uczynek”, który zasługuje na nagrodę w niebie ${ }^{68}$. Interesujące jest, że Antiocheńczyk popiera swe stwierdzenie wypowiedzią zaczerpniętą z Pierwszego Listu do Tymoteusza $(5,10)$ mówiącą o wdowach, a nie o matkach czy - ogólnie - o rodzicach. Kobietom-matkom złotousty kaznodzieja wyznacza szczególną rolę w nauczaniu i wychowywaniu córek ${ }^{69}$ :

„Matki, zajmijcie się przede wszystkim córkami! Łatwa to dla was straż. Czuwajcie, by pilnowały domu, a przede wszystkim wychowujcie je w pobożności i aby były skromne, gardziły pieniędzmi, nie stroiły się. Tak wydajcie je za mąż! Jeśli je tak ukształtujecie, ocalicie nie tylko córkę, ale i męża, który ją poślubi; nie tylko męża, lecz i synów; nie tylko synów, lecz i wnuków. Albowiem jeżeli korzeń był dobry, to i pędy lepiej wybujają, a wy za to wszystko otrzymacie zapłatę. Tak więc zawsze postępujmy, jakobyśmy dbali o pożytek nie jednej duszy, lecz przez jedną o pożytek wielu. Tak bowiem należy córce z ojcowskiego domu wychodzić do ślubu, jak atlecie ze szkoły ćwiczeń; powinna posiadać tak dokładną umiejętność życia, która by, jak zaczyn całe ciasto, miała doprowadzić do jej piękności"’70.

2. Nauczanie prywatne. Jak już wspomniano, zakaz nauczania obowiązujący kobiety jest ograniczony do nauczania publicznego, do publicznego

${ }^{66}$ Swe poglądy na temat wychowania dzieci Chryzostom najpełniej przedstawił w piśmie De inani gloria et de educandis liberis (CPG 4455), ed. A.-M. Malingrey, SCh 188, Paris 1972, thum. W. Kania: Św. Jan Chryzostom, O wychowaniu dzieci, w: Św. Jan Chryzostom, Wybór pism, PSP 13, Warszawa 1974, 157-185 oraz w: Św. Jan Chryzostom, O matżeństwie, wychowaniu dzieci i ascezie, BOK 19, Kraków 2000, 73-105. Szerzej na temat roli matki w wychowaniu dzieci zob. F. Drączkowski, Koncepcja wychowania chrześcijańskiego w ujęciu Klemensa Aleksandryjskiego oraz Jana Chryzostoma, VoxP 29 (2009) t. 53-54, 313-327; J. Jurkiewicz, ,,Mater familias” w nauczaniu św. Jana Chryzostoma, VoxP 29 (2009) t. 53-54, 223-231; S. Strękowski, Wychowanie dzieci najwazniejszym zadaniem rodziców wedlug Jana Chryzostoma, VoxP 29 (2009) t. 53-54, 407-420; A. Uciecha, Religijny program wychowania w ujęciu Jana Chryzostoma, VoxP 29 (2009) t. 53-54, 421-432; S. Wasilewski, Metody wychowawcze św. Jana Chryzostoma, VoxP 29 (2009) t. 53-54, 433-445; A. Zmorzanka, Wychowanie dziewczat w nauczaniu Jana Chryzostoma, VoxP 29 (2009) t. 53-54, 459-480. Zob. też S. Longosz, Matżeństwo, rodzina i wychowanie w nauczaniu św. Jana Chryzostoma. Materiały bibliograficzne, VoxP 29 (2009) t. 53-54, 805-812, spec. 809-812 (C. Wychowanie).

${ }^{67}$ Por. Joannes Chrysostomus, In epistulam I ad Timotheum hom. 9, 2, PG 62, 545-548.

${ }^{68}$ Por. tamże, PG 62, 546, tłum. Sinko, s. 99: „Słuchajcie tego ojcowie i matki, że wychowanie dzieci nie będzie dla was bez zapłaty"; tamże, PG 62, 548.

${ }^{69} \mathrm{Na}$ temat roli matek w wychowaniu córek zob. Zmorzanka, Wychowanie dziewczqt w nauczaniu Jana Chryzostoma, s. 459-480.

${ }^{70}$ Joannes Chrysostomus, In epistulam I ad Timotheum hom. 9, 2, PG 62, 547-548, thum. Sinko, s. $100-101$. 
wypowiadania się przed zgromadzeniem ${ }^{71}$. Natomiast jeśli chodzi o sferę prywatna, to św. Paweł nie ma nic przeciwko temu, aby kobiety udzielały rad lub stosowały perswazję ${ }^{72}$. Podobny wątek pojawia się w 4 . homilii na List do Tytusa, gdy Chryzostom analizuje wypowiedź św. Pawła, w której Apostoł

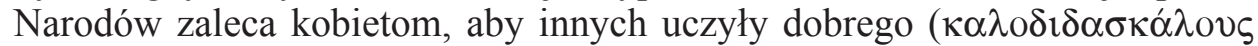
- Tt 2,3). W tym miejscu kaznodzieja musi wyjaśnić oczywistą sprzeczność istniejącą pomiędzy wskazaniem Pawła, aby starsze kobiety były nauczycielkami dobrego (por. Tt 2,3) a zakazem nauczania, wyrażonym przez Apostoła w 1 Tm 2, 12.

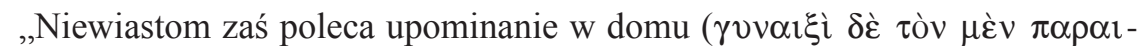

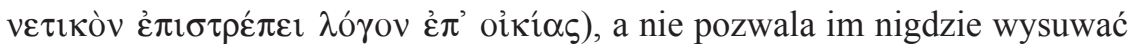
się naprzód, ani wygłaszać długich mów. Dlatego dodał: «ani panować nad mężem» $(1 \mathrm{Tm} 2,12)$ "ᄁ’3

To ograniczenie odzwierciedla starożytne przekonanie, że w przypadku kobiet karygodne jest zarówno publiczne występowanie, jak i manifestowanie swej władzy nad mężczyzną.

3. Niewchodzenie w zakres kompetencji urzędu kościelnego. Dotyczący kobiet zakaz nauczania obejmuje nauczanie i przemawianie w kościele, podczas liturgii, gdyż prowadzenie oficjalnego nauczania kościelnego wiąże się ze sprawowaniem władzy przynależącej urzędowi kościelnemu. W tym miejscu należy przytoczyć - już cytowaną - jedną z kluczowych wypowiedzi Antiocheńczyka na ten temat:

„Cóż zatem znaczą słowa Pawła: «Niewieście nauczać nie pozwalam» (1Tm $2,12$ ). Zakazuje jej przewodniczyć ( $\pi \rho 0 \varepsilon \delta \rho i ́ \alpha \varsigma)$ wśród zgromadzenia (por.

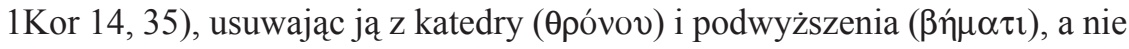
od nauczania słowem"74.

Jan Chryzostom naucza, że św. Paweł odmawia kobiecie przywileju pierwszeństwa i przewodnictwa, co określa terminem $\pi \rho \rho \delta \rho^{\prime} \alpha^{75}$. Rzeczownik ten

${ }^{71}$ Por. tenże, In epistulam ad Romanos hom. 31, 1, PG 60, 669, tłum. Sinko, t. 2, s. 451: „Przemawianie podczas zgromadzenia jest zadaniem nauczyciela”, tenże, In illud: Salutate Priscillam et Aquilam ser. 1, 3, PG 51, 192.

${ }^{72}$ Por. tenże, In epistulam ad Romanos hom. 31, 1, PG 60, 669, tłum. Sinko, t. 2, s. 451: „W jaki sposób Pryska nauczyła wiary Apolla (por. Dz 18, 24-26)? Nie wyraził się w ten sposób, aby przeszkodzić osobistej i pożytecznej perswazji”; tenże, In illud: Salutate Priscillam et Aquilam ser. 1, 3, PG 51, 192.

${ }^{73}$ Joannes Chrysostomus, In epistulam ad Titum hom. 4, 1, PG 62, 683, tłum. T. Sinko, w: Św. Jan Złotousty, Homilie na Listy Pasterskie św. Pawła i na List do Filemona (Tym. I, II. Tyt. Filem.), s. 337.

${ }^{74}$ Tenże, In epistulam ad Romanos hom. 31, 1, PG 60, 669, tłum. Sinko, t. 2, s. 450.

${ }^{75}$ Termin $\pi \rho o \varepsilon \delta \rho i ́ \alpha$ przyjmuje następujące znaczenia: „1. przywilej pierwszych miejsc na publicznych występach, w teatrze, na zgromadzeniach, jako przywilej wyróżnionych cudzoziemców, postów itp.; zastużonych obywateli, a niekiedy ich potomków; 2. autorytet; pierwszeństwo, naczelne 
wprawdzie nie występuje w Corpus Paulinum ${ }^{76}$, ale bardzo dobrze oddaje przesłanie tekstu Pawłowego i myśl kaznodziei. Antiocheńczyk podkreśla, że Apostoł Narodów odmawia też kobietom miejsca na katedrze $(\theta \rho o ́ v o \varsigma)^{77}$ i ,podwyższeniu” $(\beta \hat{\eta} \mu \alpha)^{78}$ przeznaczonym dla duchownych, z którego prowadzono nauczanie, czyli - upraszczając kwestię - „na ambonie”. Jednak kończąc swój wywód Antiocheńczyk twierdzi, że przedstawione powyżej sta-

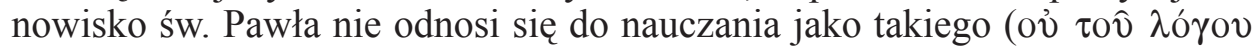
$\tau \hat{\eta} \varsigma \delta \imath \delta \alpha \sigma \kappa \alpha \lambda i \alpha \varsigma)^{79}$.

Z przeanalizowanych powyżej wypowiedzi Jana Chryzostoma jasno wynika, że bardzo mocno trzyma się on nauczania Pisma Swiętego (zwłaszcza św. Pawła), a w interesującej nas kwestii dokonuje rozróżnienia pomiędzy nauczaniem prywatnym i publicznym. Dla Chryzostoma zakaz nauczania nie jest absolutny, lecz odnosi się tylko do nauczania publicznego. Dlatego zezwala on kobietom na prywatną działalność nauczycielską. Twierdzi, że w wyjątkowych okolicznościach wierząca i mądra kobieta może nauczać męża, kiedy jest on niewierzący lub brakuje mu pełnej mądrości. Wyjątkowo, kompetencje połączone $\mathrm{z}$ wybitną cnotą mogą pozwolić kobiecie również na nauczanie innych mężczyzn, jak można to było dostrzec na przykładzie Pryscylli, ale nawet w takim przypadku, kobieta powinna bardziej ograniczać swą władzę, kreując się raczej na uczennicę a nie nauczycielkę mężczyzn. Matki-nauczycielki odgrywają też ważną rolę w edukowaniu swoich dzieci. Chryzostom wychwala kobiety z otoczenia św. Pawła, które były zaangażowane w nauczanie i przekazywanie Ewangelii. Natomiast zakazuje kobietom nauczania publicznego, gdyż jednoznacznie wiąże się ono z piastowaniem urzędu kościelnego,

stanowisko; 3. miejsce honorowe, siedzenie w pierwszym rzędzie; zwt. w Atenach, poczesne miejsce prytanów na zgromadzeniach" (Abramowiczówna III 641-642, s.v. $\pi \rho 0 \varepsilon \delta \rho i ́ \alpha)$; por. Liddell -

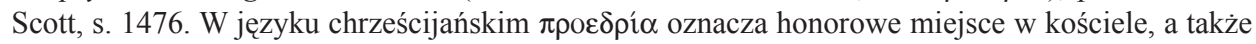
przywództwo oraz urząd prezbitera i biskupa, por. Lampe, s. 1144.

${ }^{76}$ R. Popowski (Wielki stownik grecko-polski Nowego Testamentu, Warszawa 1995) w ogóle nie odnotowuje rzeczownika $\pi \rho \circ \varepsilon \delta \rho i ́ \alpha$.

${ }_{77}$ Por. Joannes Chrysostomus, In Genesim ser. 4, 1, SCh 433, 226, ŹMT 45, 75: „Dlatego [Pa-

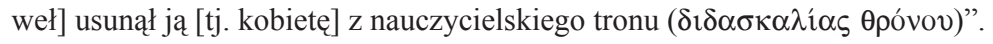

${ }^{78}$ Grecki rzeczownik $\beta \hat{\eta} \mu \alpha$ przyjmuje następujące znaczenia: „1. krok, stąpanie, chód; 2. stopa, jako miara dtugości; 3. stopień, szczebel, siedzenie; 4. Wzniesienie, trybuna" (Abramowiczówna I 432, s.v. $\beta \hat{\eta} \mu \alpha$ ); por. Lampe, s. 295; Liddell - Scott, s. 314. Szerzej na ten temat zob. J. Dauvillier, L'ambon ou bêma dans les textes de l'Église chaldéenne et de l'Église syrienne au Moyen Âge, „Cahiers Archéologiques” 6 (1952) 11-30; R.G. Coquin, Le «bîma» des églises syriennes, „L'Orient Syrien" 10 (1965) 443-474; E. Loosley, The Architecture and Liturgy of the Bema in Fourth- To-Sixth-Century Syrian Churches, Leiden 2003, 2012²; Bema, w: Sztuka świata. Stownik terminów $A-K$, t. 17, Warszawa 2013, 70.

${ }^{79}$ Joannes Chrysostomus, In epistulam ad Romanos hom. 31, 1, PG 60, 669. Por. tenże, In illud: Salutate Priscillam et Aquilam ser. 1, 3, PG 51, 192. 
zarezerwowanego dla mężczyzn. Nauczanie publiczne niewatpliwie jest manifestowaniem posiadanej władzy, na co wskazuje używanie przez Antiocheńczyka, przy omawianiu tych zagadnień, takich terminów jak tron ( $\theta$ póvos) lub miejsce nauczania $(\beta \hat{\eta} \mu \alpha)$. Kobiety, które nauczałyby, jednocześnie sprawowałyby władzę nad mężczyznami, a to stoi w sprzeczności z wykluczeniem kobiet z urzędów kościelnych. Zakaz nauczania przez kobiety argumentowany był teologicznie. Najważniejszymi argumentami są: porządek stworzenia (mężczyzna został stworzony przed kobieta) i negatywna rola, jaką kobieta odegrała przy upadku prarodziców. Normą była sytuacja, gdy mężczyzna był nauczycielem kobiety; odwrócenie tych ról było dopuszczalne jedynie w wyjątkowych okolicznościach, ale bez przejmowania władzy nad mężczyzną.

\section{THE TEACHING FUNCTION OF A WOMAN IN THE STATEMENTS OF JOHN CHRYSOSTOM}

\section{(Summary)}

The Church Fathers repeatedly spoke about the function that women should play - especially Christian women - in the communities they lived in. One of the widely discussed problems in ancient times was the question of teaching by women. It was discussed whether women in general can teach, and if so, under what circumstances? In this article I decided to investigate this issue on the basis of selected speeches of John Chrysostom. The first point of the present study notes that in ancient times the public teaching and speaking in general was a manifestation of power. The next two sections present Chrysostom's comments on this topic based on the exegesis of biblical texts 1 Timothy 2:11-15 and Romans 16:3-16.

In the final conclusions it should be underlined, that John Chrysostom firmly holds to the teaching of Scripture (especially St. Paul). He makes a distinction between private and public teaching. According to him, women can only lead private teaching activity (especially in the family), but they cannot teach in public, because such teaching is associated with the holding of an ecclesiastical office, reserved for men. A man teaches a woman, not the other way around - this is the standard situation. Reversing these roles was permitted only in exceptional circumstances.

Key words: John Chrysostom, women, teaching, power, patristic exegesis.

Słowa kluczowe: Jan Chryzostom, kobiety, nauczanie, władza, egzegeza patrystyczna.

\section{BIBLIOGRAFIA}

\section{Źródła}

Diogenes Laertius, Vitae philosophorum, ed. H.S. Long, t. 1-2, Oxonii 1964, thum. I. Krońska: Diogenes Laertios, Żywoty i poglady slynnych filozofów, Warszawa $1988^{4}$. 
Callicratidas, De domi felicitate, ed. H. Thesleff, w: The Pythagorean Texts of the Hellenistic Period, Acta Academiae Aboensis, ser. A, Humaniora, Åbo 1965, 103-107.

JoAnnes Chrysostomus, De inani gloria et de educandis liberis, ed. A.-M. Malingrey, SCh 188, Paris 1972, tłum. W. Kania: Św. Jan Chryzostom, O wychowaniu dzieci, w: Św. Jan Chryzostom, Wybór pism, PSP 13, Warszawa 1974, 157-185 oraz w: Św. Jan Chryzostom, O matżeństwie, wychowaniu dzieci i ascezie, BOK 19, Kraków 2000, 73-105.

Joannes Chrysostomus, De virginitate, ed. H. Musurillo, SCh 125, Paris 1966.

Joannes Chrysostomus, Epistulae, ed. A.-M. Malingrey, SCh 13bis, Paris 1968.

JoAnnes Chrysostomus, In epistulam ad Ephesios hom. 20, PG 62, 135-150, tłum. M. Jurek, w: Św. Jan Chryzostom, O matżeństwie, wychowaniu dzieci i ascezie, BOK 19, Kraków 2002, 47-71.

JoAnnes Chrysostomus, In epistulam ad Romanos hom., PG 60, 391-682, thum. W. Sinko: Św. Jan Chryzostom, Homilie na list św. Pawła do Rzymian, oprac. A. Baron, t. 1-2, Kraków 1995-1998.

Jonnnes Chrysostomus, In epistulam ad Titum hom., PG 62, 663-700, thum. T. Sinko, w: Św. Jan Złotousty, Homilie na Listy Pasterskie św. Pawła i na List do Filemona (Tym. I, II. Tyt. Filem.), przełożył i wstępem opatrzył T. Sinko, Kraków 1949, 305-366.

Joannes Chrysostomus, In epistulam I ad Timotheum hom., PG 62, 501-600, thum. T. Sinko, w: Św. Jan Złotousty, Homilie na Listy Pasterskie św. Pawła i na List do Filemona (Tym. I, II. Tyt. Filem.), przełożył i wstępem opatrzył T. Sinko, Kraków 1949, 25-192.

Joannes Chrysostomus, In Genesim hom., PG 53, 21-385 - 54, 385-580.

Johnnes Chrysostomus, In Genesim ser., ed. L. Brottier, SCh 433, Paris 1998, tłum. S. Kaczmarek, ŹMT 45, Kraków 2008.

Jonnnes Chrysostomus, In illud: Salutate Priscillam et Aquilam (Rz 16, 3) ser. 1, PG 51, 187-196.

Jonnnes Chrysostomus, In Matthaeum hom., PG 57-58, tłum. J. Krystyniacki (homilie 1-40, 61-90), A. Baron (homilie 41-60), w: Św. Jan Chryzostom, Homilie na Ewangelię wedtug św. Mateusza, oprac. A. Baron, t. 1-2, ŹMT 18, 23, Kraków 2000-2001.

Ocellus, De universi natura, ed. H. Thesleff, w: The Pythagorean Texts of the Hellenistic Period, Acta Academiae Aboensis, ser. A, Humaniora, Åbo 1965, 125-138.

Plutarchus, Coniugalia praecepta, ed. G.N. Bernardakis, w: Plutarchi Chaeronensis Moralia, I, Lipsiae 1888, 337-357.

\section{Opracowania}

A Patristic Greek Lexicon, ed. G.W.H. Lampe, Oxford 1961.

Balch D., Let Wives Be Submissive. The Domestic Code in I Peter, Society of Biblical Literature Monograph Series 26, Chico 1981.

Broc-Schmezer C., Les femmes de la Bible, reflets de l'évolution de Jean Chrysostome: A propos d'un passage du Traité sur la Virginité [XLVI, 2], w: Les Pères de l'Église et les femmes. Actes du Colloque de la Rochelle, 6-7 sept. 2003, éd. P.G. Delage, Rochefort 2003, 150-168.

Budzanowska D., ,C Coniugalia Praecepta” Plutarcha o życiu żon, VoxP 36 (2016) t. 65, 99-117.

Cıoffi A., La preghiera nelle omelie di Giovanni Crisostomo sulla 1 Tm, w: Historiam Perscrutari. Miscellanea di studi offerti al. prof. Ottorino Pasquato, a cura di Mario Maritano, Bibioteca di Scienze Religiose 180, Roma 2002, 785-792 
Clark E.A., The Virginal „Politeia” and Plat's „Republic”: John Chrysostom on Women and the Sexual Relation, w: taż, Jerome, Chrysostom and Friends. Essays and Translations, Studies in Women and Religion 1, New York - Toronto 1979, 1-34.

Coquin R.G., Le «bîma» des églises syriennes, „L'Orient Syrien” 10 (1965) 443-474.

DAuvillier J., L'ambon ou bêma dans les textes de l'Église chaldéenne et de l'Église syrienne au Moyen Âge, „Cahiers Archéologiques” 6 (1952) 11-30.

Drączkowski F., Koncepcja wychowania chrześcijańskiego w ujęciu Klemensa Aleksandryjskiego oraz Jana Chryzostoma, VoxP 29 (2009) t. 53-54, 313-327.

DybaŁa J., Władza męża nad żona w nauczaniu Jana Chryzostoma, „Piotrkowskie Zeszyty Historyczne" 12 (2011) 4-17.

Grubbs J.E., Women and the Law in the Roman Empire: A Sourcebook on Marriage, Divorce and Widowhood, London - New York 2002.

Guthrie K.S. - Fideler D., The Pythagorean Sourcebook and Library. An Anthology of Ancient Writings Which Relate to Pythagoras and Pythagorean Philosophy, Grand Rapids 1987.

HANSEN M.H., Demokracja ateńska w okresie Demostenesa: struktura, zasady i ideologia, thum. R. Kulesza, Warszawa 1999.

Hawley R., Practicing What You Preach. Plutarch's Sources and Treatment, w: Plutarch's Advice to the Bride and Groom, and A Consolation to His Wife, ed. S.B. Pomeroy, New York 1999, 116-127.

Hemelrijk E.A., Matrona Docta. Educated Women in the Roman Elite from Cornelia to Julia Domna, London - New York 1999.

Jurkiewicz J., „Mater familias” w nauczaniu św. Jana Chryzostoma, VoxP 29 (2009) t. 53-54, 223-231.

Karras V., Male Domination of Woman in the Writings of Saint John Chrysostom, GOTR 36 (1991) 131-139.

Kunst Ch., Eheallianzen und Ehealltag in Rom, w: Frauenwelten in der Antike, Geschlechtsordnung und weibliche Lebenspraxis, hrsg. T. Späth - B. Wagner-Hasel, Stuttgart - Weinmar 2000, 32-52.

Liddell H. G. - Scott R., Greek - English Lexicon, Oxford 1958.

Longosz S., Matżeństwo, rodzina i wychowanie w nauczaniu św. Jana Chryzostoma. Materiaty bibliograficzne, VoxP 29 (2009) t. 53-54, 805-812.

Loosley E., The Architecture and Liturgy of the Bema in Fourth-To-Sixth-Century Syrian Churches, Leiden 2003, $2012^{2}$.

Marshall A.J., Roman Ladies on Trial: The Case of Maesia of Sentinum, „Phoenix” 44 (1990) 46-59.

Mayer W., The Homilies of St John Chrysostom: Provenance. Reshaping the Foundations, OCA 273, Rome 2005.

McClure L., Spoken Like a Woman: Speech and Gender in Athenian Drama, Pnnceton 1999.

O’Collins G. - Farrugia E.G., Leksykon pojęć teologicznych i kościelnych z indeksem angielsko-polskim, tłum. J. Ożóg - B. Żak, Kraków 2002.

Pagels E., The Politics of Paradise: Augustine's Exegesis of Genesis 1-3 versus that of John Chrysostom, HTR 78 (1985) 67-99.

Papageorgiou P., Chrysostom and Augustine on the Sin of Adam and Its Consequences, VTQ 39 (1995) 361-378.

Popowski R., Wielki słownik grecko-polski Nowego Testamentu, Warszawa 1995. 
RaAflaub K.U., Aristocracy and Freedom of Speech in the Greco-Roman World, w: Free Speech in Classical Antiquity, ed. I. Sluiter - R.M. Rosen, Mnemosyne, Bibliotheca Classica Batava, Supplementum 254, Leiden - Boston 2004, 41-61.

Rist J.M., Stoic Philosophy, Cambridge - London 1969.

Roisman H.M., Women's Free Speech in Greek Tragedy, w: Free Speech in Classical Antiquity, ed. I. Sluiter - R.M. Rosen, Mnemosyne, Bibliotheca Classica Batava, Supplementum 254, Leiden - Boston 2004, 91-114.

Schroeder C.P., The Mystery of Love: Paradigms of Marital Authority and Submission in the Writings of St. John Chrysostom, VTQ 44 (2000) fasc. 2, 143-168.

Stownik grecko-polski, red. Z. Abramowiczówna, t. 1-4, Warszawa 1958-1965.

STRĘKOwski S., Wychowanie dzieci najważniejszym zadaniem rodziców wedtug Jana Chryzostoma, VoxP 29 (2009) t. 53-54, 407-420.

Sztuka świata. Słownik terminów A-K, t. 17, Warszawa 2013.

TAFT R.F., Women at Church in Byzantium, DOP 52 (1998) 27-87.

UCIECHA A., Religijny program wychowania w ujęciu Jana Chryzostoma, VoxP 29 (2009) t. 53-54, 421-432.

Vernant J.-P., The Origins of Greek Thought, New York 1982.

Wasilewski S., Metody wychowawcze św. Jana Chryzostoma, VoxP 29 (2009) t. 53-54, 433-445.

Zmorzanka A., Wychowanie dziewczat w nauczaniu Jana Chryzostoma, VoxP 29 (2009) t. 53-54, 459-480.

Zyzak W., Parrezja, EK XIV 1374-1375. 
